\title{
年報 発刊によせて
}

\section{照明年報委員会}

\section{委員長 阪 口忠 雄*}

70 年代は人間尊重の時代であるといわれて，はなばな しくスタートした 1970 年代も，すでに 3 年が 経過した にもかかわらず, 人間のための住みよい環境づくりとし ての積極的な施策は，いまだに汪とんど見るべき成果が あげられて打らず，反面，公害間題などの消極的な面ば かりがやたらと強調されて，かえってとげとげしさの増 した世の中になったよらな気のする今日このごろではめ るが，照明の分野に和いては幸いなことに，遅々として ではあるが，生産中心の照明から人間中心の照明への転 換の道を歩みはじめているきざしがみえることは喜ばし いことである．この年報でも随所にみられるように，人 間尊重の照明が志向されるにつれて, 明視論一辺倒の照 明から環境の快適性を目ざした照明へとその幅が広が り, それに伴って照明器具, 照明手法の多様化, ファッ ション化が目だち，一部には行き過ぎないでもないが， はなやかな器具, 快いきらめきをるった照明手法がだん だん生活環境に定着するよらになってきた.これがここ 数年来の照明界の最も大さな特徴の一つであるう。

こらした大きな底流は感じられるものの，この年度の 照明界には，例年のような特筆するほどのトピックス的 なものは市りなかったようであるが，去のなかから多 少とも特徵的な話題䘮拾いあげると次の上らである.

前年度のドルショックでいささか低迷を続けていた照 明界も本年度後半からようやく立ち直り, 年末には一部 の照明器具では在庫が出尽くして, 品不足が目だつとい ら現象まで生じ，好況裡に年を越すことができ，一応の 安定状態を回復したといえよう.

また世界的なエネルギー資源の危期が話題を呼び，か てて加壳て, 公害問題がからんだ発電所建設用地の立地 難に基づく電力不足から，わが国のエネルギー問題が大 きくクローズアップしてきたのもこの年である.あらゆ る分野で, 電力資源の有効利用のための省エネルギーを 真剣に考光る必要に迫られてきて，照明もまた省エネル ギー対策に即応した照明手法を開拓しようという気運が 出はじめてきているが，これを現在台頭しつつある人間 尊重の照明といかなる形で調和させるかということが,

* 京都大学工学部
今後の大きな課題となるであろう.

一方, 工事の省力化とごみ公害対策上好都合な相包物 の処理不要といらメリットを兼ねたンステム天井化がま すます普及し，ビル照明だけでなく，店舗照明などの分 野にまで進出するようになり，今後もその傾向はますま す拡大するものと考光られる.

昭和 47 年 5 月 13 日の大阪千日前デパートの火苂は 118 名の死亡者を出す大惨事であったが，これを契機と して，防災問題の重要性があらためてクローズアップさ れ, 消防法の改正も行なわれ, 防災設備の強化がはから れることになり，前年度に設置が義務づけられた非常用 照明器具とともに, 防災設備の充実はこれからの重要課 題の一つとなるであるう. 本年報も今回から第 5 章の夕 イトルを「配線打よび器具」から「配線特よび防災機 器」と改めて，そのすう勢に対処することとした。

光源開発の面では, この年度は特湿著な進歩はみら れなかったが，その中でもわずかに特徵的なるのは， ミ ュヘンオリンピックの競技場照明に，寿命を犠牲にして 高効率, 高演色性をはかったメタルハライドランプが使 用され，カラーテレビ中継に好成績を収めたことで，年 間使用時間の短い競技場照明に対する新しい考光方とし て，今後も参考になるであるう。また，わが国では比較 的普及の遅孔ていた高圧ナトリウムランプも，ようやく 高速道路のインターチェージンやジャンクションに本格 的使用されるようになり，今後の発展普及が期待され る.

学会に物ける委員会活動は例年同様, 活発に行なわれ たが，そのらちでも特筆すべき活躍は沖繩国際海洋博照 明施設研究委員会が，沖繩国際海洋博覧会協会からの委 託に基づいて，同会場照明システム計画報告書を作成し たことで, この成果が今後さらに発展的に展開されて, 来たるべき 1975 年の沖繩国際海洋博に, その華麗な花 を開くことを期待してやまない。

最後に本年度からの新しい計画として, 欧米諸国の照 明学会に, その国のその年度に打ける優秀な照明施設の 紹介を传頼したところ, 多くの国々から協力が得られ， この年報のページを飾ることができた．付記して深謝の 意を表する次第である. 